\title{
IMPROVEMENT OF THE CORROSION BEHAVIOR OF ALUMINUM ALLOY 6061-T6 WITH YTTRIUM AND LANTHANUM CONVERSION COATINGS
}

\author{
IZBOLJŠANJE KOROZIJSKE ODPORNOSTI ALUMINIJEVE \\ ZLITINE 6061-T6 S KONVERZIJSKIMI PREVLEKAMI NA OSNOVI \\ ITRIJA IN LANTANA
}

\author{
Djillali Bekhiti ${ }^{1}$, Juan Creus ${ }^{2}$, Nadir Mesrati ${ }^{3}$, Abderrezak Abdi ${ }^{1}$, Hiba Messaoudi ${ }^{4}$ \\ ${ }^{1}$ Polytechnic Military School, Bordj el Bahri, 1611 Algiers, BP17, Algeria \\ ${ }^{2}$ University of La Rochelle, Laboratory of Engineering Science for the Environment, UMR 7356 CNRS, La Rochelle, France \\ 3 Polytechnic of Algiers, National High School, 1611 Algiers, Algeria \\ ${ }^{4}$ University of 20 August 1955 of Skikda, Faculty of Science, Department of Chemistry, Algeria \\ bekhitidjillali@gmail.com
}

Prejem rokopisa - received: 2017-09-26; sprejem za objavo - accepted for publication: 2017-11-03

doi:10.17222/mit.2017.160

\begin{abstract}
In this study, yttrium- and lanthanum-based conversion coatings were deposited on a 6061-T6 aluminum alloy with cathodic electrochemical deposition using $\mathrm{Y}$ - and La-nitrate precursors. The optimum $\left[\mathrm{La}^{3+}\right] /\left[\mathrm{Y}^{3+}\right]$ ratio was evaluated with cyclic-voltammetry (CV) curves. The influence of the conversion-treatment time was studied by performing the experiment for periods of 10 and 20 minutes. Optical microscopy was used to determine the coating morphology and the anticorrosive properties were studied using linear polarization (LP) and electrochemical impedance spectroscopy (EIS) in a 5-g/L NaCl solution. The electrochemical results revealed an obvious improvement in the corrosion resistance against the aggressive media after an extended imersion test for $48 \mathrm{~h}$, indicating a good efficiency of the Y- and La-conversion coating.

Keywords: aluminum alloy, 6061-T6, conversion coating, rare earth elements, lanthanum, yttrium
\end{abstract}

$\mathrm{V}$ pričujočem članku avtorji opisujejo nanos konverzijske (pretvorbene) prevleke na osnovi itrija in lantana na Al zlitino 6061-T6 s katodno elektrokemijsko depozicijo (nanosom) z uporabo Y in La-nitratnih prekurzorjev (izhodnih surovin). S cikličnimi voltametričnimi (CV; angl.: Cyclic Voltammetry) krivuljami so ovrednotili optimalno razmerje $\left[\mathrm{La}^{3+}\right] /\left[\mathrm{Y}^{3+}\right]$. Studirali so vplive časa na pretvorbo z izvedbo 10 in 20 minutnih preizkusov. S pomočjo svetlobnega mikroskopa so podali morfologijo prevleke. S pomočjo linearne polarizacije (LP) in elektrokemične impedančne spektroskopije (EIS) v $5 \mathrm{~g} / \mathrm{L} \mathrm{NaCl}$ pa so študirali korozijsko odpornost prevleke. Rezultati elektrokemijskih preiskav so pokazali jasno izboljšanje protikorozijske zaščite $v$ agresivnem mediju po podaljšanem 48 urnem potopnem preizkusu. To kaže na dobro učinkovitost izbrane obdelave za izdelavo $\mathrm{Y}$ in La pretvorbenih prevlek.

Ključne besede: zlitina na osnovi aluminija, 6061-T6, pretvorbena prevleka, redki elementi zemlje, lantan, itrij

\section{INTRODUCTION}

Aluminum alloy 6061-T6 is widely used due to its significant characteristics such as low cost, high strength-to-weight ratio and easy workability. ${ }^{1}$ For this reason, it is commonly used in modern construction, automotive and aerospace industries. ${ }^{2}$ Nevertheless, the presence of multiple heterogeneities in Al-alloy classes originates from the hardening as heat treatments significantly reduce the corrosion resistance. These heterogeneities, mainly associated with the presence of intermetallic precipitations (IMs), are the source of localized corrosion when in contact with a corrosive environment. ${ }^{3}$ Localized corrosion generally occurs in the form of pitting corrosion; it is initiated at discrete sites, in the vicinity of Fe-containing intermetallic phases of 6xxx aluminum alloys. ${ }^{4-8}$ Metal impurities, even in small amounts, are can cause the formation of new phases, acting as cathodes in relation to the aluminum matrix. Indeed, it was shown that intermetallic particles in $2 \mathrm{xxx}$ aluminum alloys, for example, are initially anodic to the matrix and progressively become cathodic due to the selective corrosion of their less noble constituents that provoke the corrosion of the adjacent matrix..$^{9,10}$ Rareearth conversion coating is one of the highly attractive techniques used for improving the corrosion resistance of aluminum and its alloys, including also chemical vapor deposition (CVD), physical vapor deposition (PVD), thermal spray coating, anodizing technique, organic coating and micro-arc oxidation (MAO).

Since chrome (VI) is considered as a health and environmentally hazardous compound, ${ }^{11}$ rare-earth elements (REEs) are considered as good alternatives to chromium (VI)-based chemical-conversion coatings, commonly used for the final finish pretreatment. ${ }^{12}$ Among the REEs, lanthanum and yttrium attract much attention owing to their properties, creating a remarkable inhibition to the localized corrosion of aluminum alloys. ${ }^{13-15}$ Indeed, they exhibit a strong ionic character enabling them to react with hydroxyl anions in aqueous media to produce insol- 
uble and adherent hydroxide/oxide deposits, increasing the blocking effect and providing a high stability against mechanical abrasion and catalytic activity. ${ }^{16}$

The aim of this work was to evaluate the efficiency of yttrium- and lanthanum-conversion coatings, made with cathodic electrodeposition, for the corrosion protection of the 6061-T6 aluminum alloy used as the substrate in chloride-containing media.

\section{EXPERIMENTAL PART}

\subsection{Lanthanum- and yttrium-conversion coating proce- dures}

The samples used were disks of aluminum alloy 6061-T6 with a 30-mm diameter, encapsulated in epoxy resin. The nominal composition (\% by weight) is given in Table 1. Before the conversion-coating treatment, they were grinded with $(600,800,1200,2400$ and 4000) grit $\mathrm{SiC}$ paper, using demineralized water as the lubricant. Then they were washed with ethanol and demineralized water and dried. Lanthanum and yttrium conversion coatings were performed by means of the galvanostatic technique at room temperature, using $\mathrm{La}\left(\mathrm{NO}_{3}\right)_{3} \cdot 6 \mathrm{H}_{2} \mathrm{O}$ $(0.1 \mathrm{M})$ and $\mathrm{Y}\left(\mathrm{NO}_{3}\right)_{3} \cdot 6 \mathrm{H}_{2} \mathrm{O}(0.1 \mathrm{M})$ as the precursors (Prolabo, $99 \%$ ). The experiments were conducted in a standard three-electrode electrochemical cell in an aerated solution and under moderate stirring. All the electrochemical measurements were performed using an Autolab $302 \mathrm{~N}$ potentiostat/galvanostat coupled to a PC and controlled with the GPES software. The aluminumalloy samples served as the working electrodes, a Pt-wire as the counter electrode and a saturated calomel electrode (SCE) as the reference electrode $(0.242 \mathrm{~V}$ vs. SHE). Electro-deposition was performed at a cathodic current of $2.5 \mathrm{~mA}$ for $10 \mathrm{~min}$ and $20 \mathrm{~min}$. Preliminary cyclicvoltammetry $(\mathrm{CV})$ curves were plotted from $-1 \mathrm{~V}$ to $0.2 \mathrm{~V}$ (vs. $S C E$ ) around the open circuit potential $(O C P)$ at a $0.1-\mathrm{mV} / \mathrm{s}$ scan rate, in different solutions based on $\mathrm{La}\left(\mathrm{NO}_{3}\right)_{3}(0.01 \mathrm{M})$ and $\mathrm{Y}\left(\mathrm{NO}_{3}\right)_{3}(0.01 \mathrm{M})$ as the single precursors, and in a mixture with the $\left[\mathrm{La}^{3+}\right] /\left[\mathrm{Y}^{3+}\right]$ ratios of $1 / 1,1 / 3$ and $3 / 1$. The total concentration of $\left(\left[\mathrm{La}^{3+}\right]+\left[\mathrm{Y}^{3+}\right]\right)$ was kept to be $0.01 \mathrm{M}$.

Table 1: Nominal composition of the 6061 aluminum alloy

\begin{tabular}{|c|c|c|c|c|c|c|c|c|c|c|}
\hline \multicolumn{10}{|c|}{ Elements $(w / \%)$} \\
\hline $\mathrm{Al}$ & $\mathrm{Mg}$ & $\mathrm{Si}$ & $\mathrm{Ti}$ & $\mathrm{Cr}$ & $\mathrm{Mn}$ & $\mathrm{Fe}$ & $\mathrm{Ni}$ & $\mathrm{Cu}$ & $\mathrm{Zn}$ & $\mathrm{Ga}$ \\
\hline 97.78 & 1.16 & 0.01 & 0.01 & 0.18 & 0.11 & 0.22 & 0.02 & 0.28 & 0.20 & 0.01 \\
\hline
\end{tabular}

\subsection{Characterization methods}

The coating morphologies were determined with optical microscopy (OM) using a Leica DM 2500M microscope, controlled by the Leica software. To provide more information about the corrosion behavior and the efficiency of RREs conversion coatings, electrochemical experiments were performed at room temperature in a standard three-electrode cell in an aerated $\mathrm{NaCl}$ solution
(5 g/L) under magnetic stirring $\left(200 \mathrm{~min}^{-1}\right)$, using an Autolab 302 N PGSTAT. A Pt-foil served as the counter electrode and the $S C E$ as the reference electrode. The polarization curves were recorded from $-150 \mathrm{mV}$ to $+150 \mathrm{mV}$ around $O C P$, with a $1 \mathrm{mV} / \mathrm{s}$ scan rate. Electrochemical impedance spectroscopy (EIS) was performed in the AC-frequency domain in a range of $1 \mathrm{MHz}-0.25 \mathrm{~Hz}$, with a perturbation amplitude of $10 \mathrm{mV}$. Each experiment was conducted three times for the testing reproducibility.

\section{RESULTS AND INTERPRETATION}

\subsection{Lanthanum- and yttrium-conversion coatings}

The rare-earth metal hydroxides $\mathrm{La}(\mathrm{OH})_{3}\left(\Delta \mathrm{G}^{\circ}=\right.$ $-1272,8 \mathrm{~kJ} / \mathrm{mol})$ and $\mathrm{Y}(\mathrm{OH})_{3}\left(\Delta \mathrm{G}^{\circ}=-1299,0 \mathrm{~kJ} / \mathrm{mol}\right)$ were deposited and grown on the aluminum surface owing to the local $\mathrm{pH}$ increase through the electrogeneration of the hydroxyl ions $\left(\mathrm{OH}^{-}\right)$from the reduction of both dissolved $\mathrm{O}_{2}$ and $\mathrm{H}_{2} \mathrm{O}$ molecules, following Equations (1) and (3), in agreement with ${ }^{3}$ :

$$
\begin{gathered}
\mathrm{O}_{2, \text { aq }}+2 \mathrm{H}_{2} \mathrm{O}+4 \mathrm{e}^{-} \rightarrow 4 \mathrm{OH}^{-} \\
E_{\mathrm{O}_{2} / \mathrm{OH}^{-}}(V \text { vs. } E N H)=0.32-0.06 \mathrm{pH} \\
2 \mathrm{H}_{2} \mathrm{O}+2 \mathrm{e}^{-} \rightarrow \mathrm{H}_{2}+2 \mathrm{OH}^{-} \\
E_{\mathrm{H}_{2} \mathrm{O} / \mathrm{H}_{2}}(V \text { vs. } E N H)=-0.06 \mathrm{pH}
\end{gathered}
$$

For high cathodic-potential values, the current is mainly associated with the hydrogen production because of the low dissolved-oxygen content in the aqueous media, evaluated to be $8.26 \mathrm{mg} / \mathrm{L}\left(\sim 2.6 \times 10^{-4}\right)$ at $25^{\circ} \mathrm{C} .{ }^{17}$

According to some authors, ${ }^{18}$ the cathodic reduction of nitrate ions may also produce an additional quantity of $\mathrm{OH}^{-}$ions according to Equation (5):

$$
\begin{gathered}
\mathrm{NO}_{3}^{-}+\mathrm{H}_{2} \mathrm{O}+2 \mathrm{e}^{-} \leftrightarrow \mathrm{H}_{2}+2 \mathrm{OH}^{-} \\
E_{\mathrm{NO}_{3}^{-} / \mathrm{NO}_{2}^{-}}(V \text { vs. } E N H)=0.01-0.06 \mathrm{pH}
\end{gathered}
$$

It is well known that for the weakly soluble metallic hydroxides such as lanthanum and yttrium hydroxides, the $\mathrm{pH}$ is one of the most critical parameters. Indeed, the

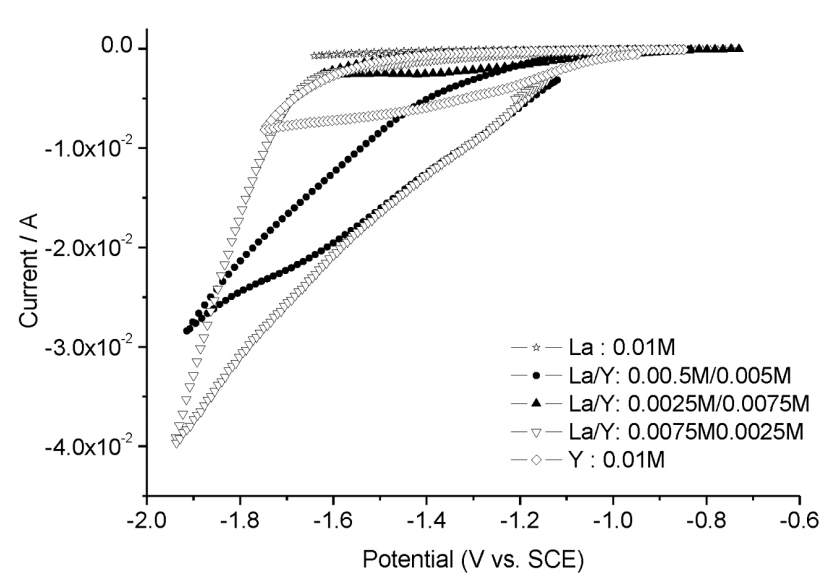

Figure 1: $\mathrm{CV}$ curves plotted from $-1 \mathrm{~V}_{\mathrm{SCE}}$ to $0.2 \mathrm{~V}_{\mathrm{SCE}}$, in different solutions based on $\mathrm{La}\left(\mathrm{NO}_{3}\right)_{3}(0.01 \mathrm{M})$ and $\mathrm{Y}\left(\mathrm{NO}_{3}\right)_{3}(0.01 \mathrm{M})$ at a scan rate of $0.1 \mathrm{~m} \mathrm{~s}^{-1}$ 


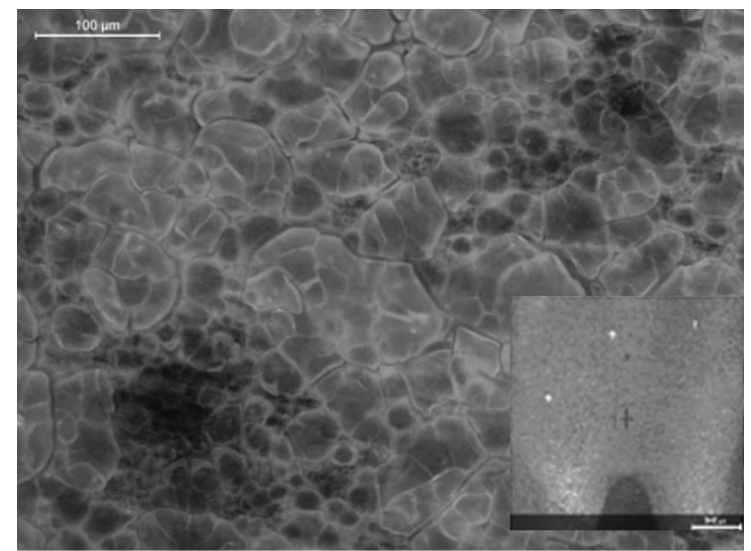

Figure 2: Morphology of the Y/La-conversion coating performed at $2.5 \mathrm{~mA}$ for $20 \mathrm{~min}$

solid-phase precipitation for both $\mathrm{La}(\mathrm{OH})_{3}(\mathrm{Ks}=$ $\left.2 \times 10^{-22}\right)$ and $\mathrm{Y}(\mathrm{OH})_{3}\left(\mathrm{Ks}=1 \times 10^{-22}\right)$ occurs when $[\mathrm{La} 3+] \times[\mathrm{OH}-]^{3}$ and $\left.] \mathrm{Y}^{3+}\right] \times\left[\mathrm{OH}^{-}\right]^{3}$ are higher than theirs corresponding solubility products. $\mathrm{La}^{3+}$ and $\mathrm{Y}^{3+}$ are considered as stronger Lewis acids due to their strong ionic characters. They interact, in an aqueous solution, with $\mathrm{H}_{2} \mathrm{O}$ molecules in the hydrolysis process.

Figure 1 shows $\mathrm{CV}$ curves plotted around the $O C P$, from -1 to $0.2 \mathrm{~V}_{\mathrm{SCE}}$, in different solutions based on $\mathrm{La}\left(\mathrm{NO}_{3}\right)_{3}(0.01 \mathrm{M})$ and $\mathrm{Y}\left(\mathrm{NO}_{3}\right)_{3}(0.01 \mathrm{M})$. A significant change in the current intensity was observed for solutions based on the mixture of La- and Y-nitrate salts, leading to an evident hysteresis in the reverse scan, in agreement with the previous research on rare-earth conversion coatings. ${ }^{3,19}$ Additionally, we obtain the best current density with the $\left[\mathrm{La}^{3+}\right] /\left[\mathrm{Y}^{3+}\right]$ ratio of $3 / 1$ since oxygen- and water-reduction reactions provide for higher amounts of $\mathrm{OH}^{-}$ions necessary for obtaining a thicker deposit with a more compact structure, able to stop the diffusion of oxygen dissolved to reduce or prevent corrosion.

\subsection{Microstructural characterization of rare-earth con- version coatings}

In Figure 2, the obtained ceramic-coating morphology for the specimen treated for $20 \mathrm{~min}$ is presented. Optical microscopy revealed a typical compact $\mathrm{La} / \mathrm{Y}$-conversion coating deposited over the entire substrate surface (Figure 2, the insert). The microstructure appears as homogenous agglomerates of particles with no particular orientation and with grain sizes between $10 \mu \mathrm{m}$ and $150 \mu \mathrm{m}$.

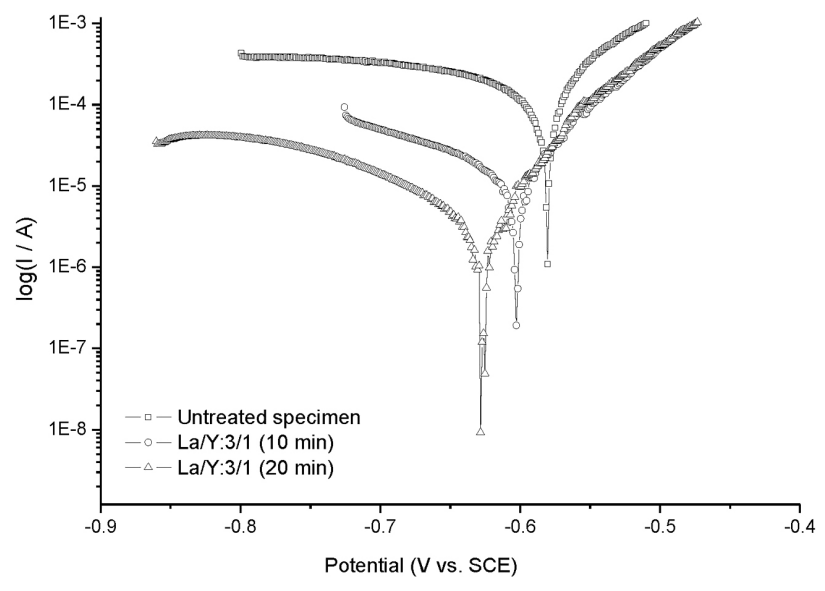

Figure 3: $\operatorname{Lg} i$ versus the potential characteristic of 6064-T6

\subsection{Electrochemical characterization}

\subsubsection{Polarization measurement}

Figure 3 shows semi-logarithmic plots $\left.\lg i\left(E_{\mathrm{SCE}}\right)\right)$ for the treated and untreated specimens in the $0.5-\%$ aerated $\mathrm{NaCl}$ solution. The treated specimens show an obvious decrease in the corrosion-current density, indicating an improvement in the corrosion resistance. Many authors $^{3,20}$ indicate that the REE deposit starts to grow over the cathodic sites formed by intermetallic particles of the aluminum matrix, where the local alkalization occurs, due to the generation of hydroxyl $\left(\mathrm{OH}^{-}\right)$ions. In Table 2, we see the potential corrosion $\left(E_{\text {corr }}\right)$ and the kinetic values such as the corrosion current density $\left(i_{\text {corr }}\right)$, the Tafel parameters $\left(b_{c}\right.$ and $\left.b_{\mathrm{a}}\right)$ and the inhibition efficiency $(\eta)$. The specimen treated for 20 minutes generates more protective coating than that treated for 10 minutes. Indeed, specimen 6061 treated for longer times (20 min) had the lowest $i_{\text {corr }}$ values, $4.92 \mu \mathrm{A} / \mathrm{cm}^{2}$ and $2.97 \mu \mathrm{A} / \mathrm{cm}^{2}$, respectively. The polarization resistance $\left(R_{\mathrm{p}}\right)$ is given as a function of the corrosion current density and the Tafel parameters $b_{\mathrm{a}}(>0)$ and $b_{\mathrm{c}}(<0)$ are expressed in the V/current decade, according to Relation $(4):{ }^{21}$

$$
R_{p}\left(\Omega \mathrm{cm}^{2}\right)=\left[2.303 \times i_{\text {corr }}\left(\frac{1}{b_{\mathrm{c}}}+\frac{1}{b_{\mathrm{a}}}\right)\right]^{-1}
$$

For the treatment time of 20 minutes, the $R_{\mathrm{p}}$ increases by one order of magnitude more than for the untreated sample. In addition, from Table 2 , it can be clearly seen that $\left(b_{\mathrm{a}}<\left|b_{\mathrm{c}}\right|\right)$ indicates a cathodic controlling polarization of the electrochemical systems.

Table 2: Electrochemical parameters obtained from polarization curves

\begin{tabular}{|c|c|c|c|c|c|c|c|}
\hline $\begin{array}{c}\text { Time } \\
(\mathrm{min})\end{array}$ & $\begin{array}{c}-E_{\text {corr }} \\
(\mathrm{mV} \text { vs. SCE })\end{array}$ & $\begin{array}{c}i_{\text {corr }} \\
\left(\mu \mathrm{A} \mathrm{cm} \mathrm{cm}^{-2}\right)\end{array}$ & $\begin{array}{c}-\beta_{\mathrm{c}} \\
(\mathrm{mV} / \mathrm{dec})\end{array}$ & $\begin{array}{c}\beta_{\mathrm{a}} \\
(\mathrm{mV} / \mathrm{dec})\end{array}$ & $\begin{array}{c}R_{\mathrm{p}} \\
\left(\Omega . \mathrm{cm}^{2}\right)\end{array}$ & $\begin{array}{c}\eta(\%) \\
\text { Porosity }\end{array}$ \\
\hline Untreated & 580 & 162 & 351 & 84 & 296 & - \\
10 & 602 & 14.7 & 181 & 65 & 2996 & 90 \\
20 & 620 & 2.97 & 71 & 45 & 17966 & 98 \\
\hline
\end{tabular}


The inhibiting efficiency $(\eta)$, calculated using the corrosion current densities of the treated $\left(i_{\text {corr }}\right)$ and untreated $\left(i_{\text {corr }}^{0}\right)$ specimens according to equation (5), increases with the time treatment. ${ }^{22}$

We obtained $98 \%$ for the 20 -min treatment time, indicating a good inhibiting efficiency.

$$
\eta(\%)=\left(1-\frac{i_{\text {corr }}}{i_{\text {corr }}^{0}}\right) \times 100
$$

The total coating porosity, $P$, was evaluated using the empirical equation (9), assuming that the conversioncoating deposit is inert under a low anodic-bias potential2 $^{23}$ :

$$
P=\frac{R_{\mathrm{p}, \mathrm{s}}}{R_{\mathrm{p}}} \times 10^{-\left|\frac{\Delta E_{\text {corr }}}{b_{\mathrm{a}}}\right|}
$$

where $R_{\mathrm{p}, \mathrm{s}}$ and $R_{\mathrm{p}}$ are the polarization resistances of the treated and untreated aluminum-alloy specimens, respectively. $\Delta E_{\text {corr }}$ is the free-corrosion potential difference between the coated and blank aluminum-alloy substrates, and ba is the anodic Tafel slope associated with the substrate.

Since the corrosion resistance of a coating is directly related to its porosity, aggressive species of the environment, in the first instance, $\mathrm{O}_{2}$ and $\mathrm{Cl}^{-}$, are better inhibited and their diffusion towards the metallic subsurface is substantially reduced with a low porosity. The obtained porosity values of the samples treated for $10 \mathrm{~min}(P=$ $0.054)$ and $20 \mathrm{~min}(P=0.007)$ indicate that the prolongation of the treatment time allows a development of a more compact deposit, reducing the porosity by nearly 13 times.

\subsubsection{Electrochemical impedance spectroscopy}

Figure 4 shows the Nyquist diagrams recorded after $48 \mathrm{~h}$ of contact with the $5-\mathrm{g} / \mathrm{L} \mathrm{NaCl}$ solution over a frequency range of $1 \mathrm{MHz}-10 \mathrm{mHz}$. It clearly shows depressed semicircles observed in a large frequency domain, revealing a significant rise in the cell impedance

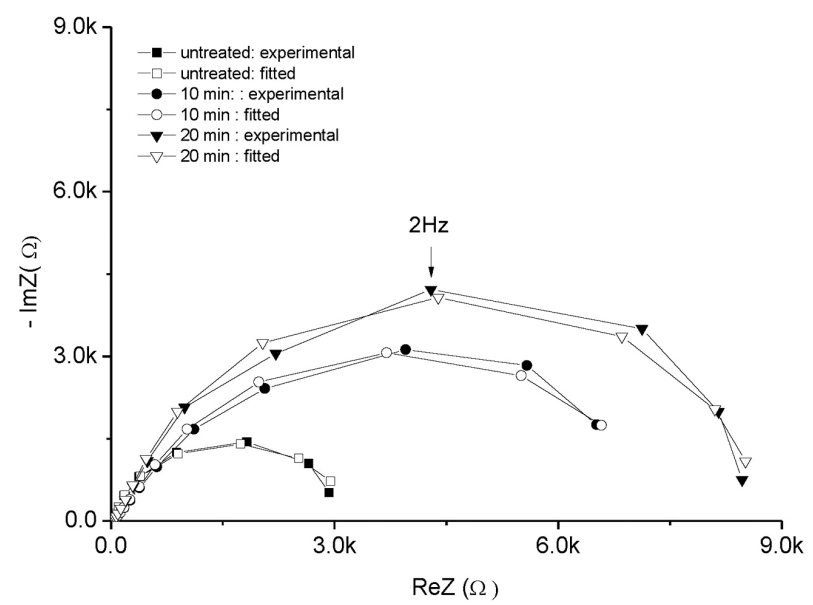

Figure 4: Nyquist diagram recorded after the 48-h contact with the $5 \mathrm{~g} / \mathrm{L} \mathrm{NaCl}$ solution, over a frequency range of $1 \mathrm{MHz}-10 \mathrm{mHz}$

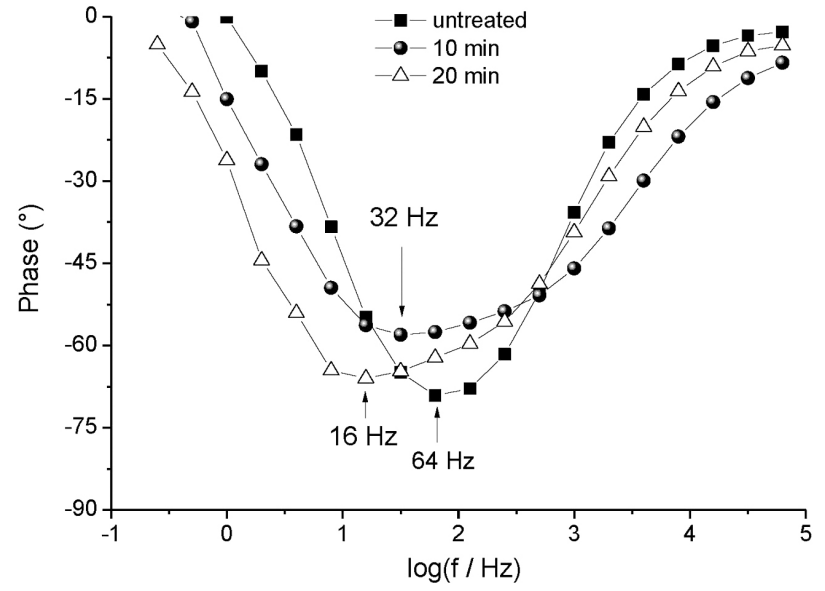

Figure 5: Bode diagram $\lg (Z)$ versus $\lg (f)$ after immersion in the $5 \mathrm{~g} / \mathrm{L}$ $\mathrm{NaCl}$ solution for $48 \mathrm{~h}$

for the treated specimens in comparison with the untreated ones, owing to the presence of a compact protective layer. Indeed, it can be clearly seen that the apparent diameter of the non-ideal semicircles increases with the treatment time. This result confirms those obtained with linear polarization.

Figure 5 establishes a distorted phase versus the $\lg (f)$ plot for both treated specimens in contrast to the untreated one, indicating two time constants. The best equivalent-circuit model describing the electrochemical behavior of the treated materials (Figure 6a), combines the internal resistance $\left(R_{i}\right)$ in the series with two RQ loops; the first loop is associated with the ionic chargetransfer resistance $\left(R_{\mathrm{ct}}\right)$, in parallel with the constant phase element (CPEdl) related to the double-layer capacitance; the second loop is connected with the faradic resistance (Rf) and the constant phase element (CPEb) related to the bulk capacitance. However, the experimental data of the untreated specimen are well fitted with the equivalent circuit model in Figure $\mathbf{6 b}$.

The CPE, given with Equation (10), is used to avoid the data dispersion due to both porosity and surfaceroughness: ${ }^{24}$

$$
Z_{\mathrm{CPE}}=\left[Q(j \omega)^{\alpha}\right]^{-1}
$$

(a)

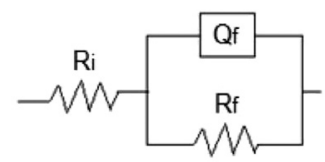

(b)

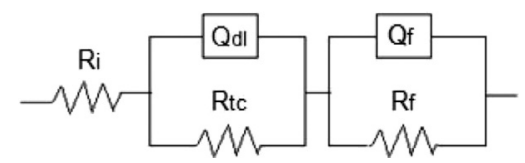

Figure 6: Equivalent circuit models obtained by fitting the EIS data: a) for untreated and b) treated specimens 


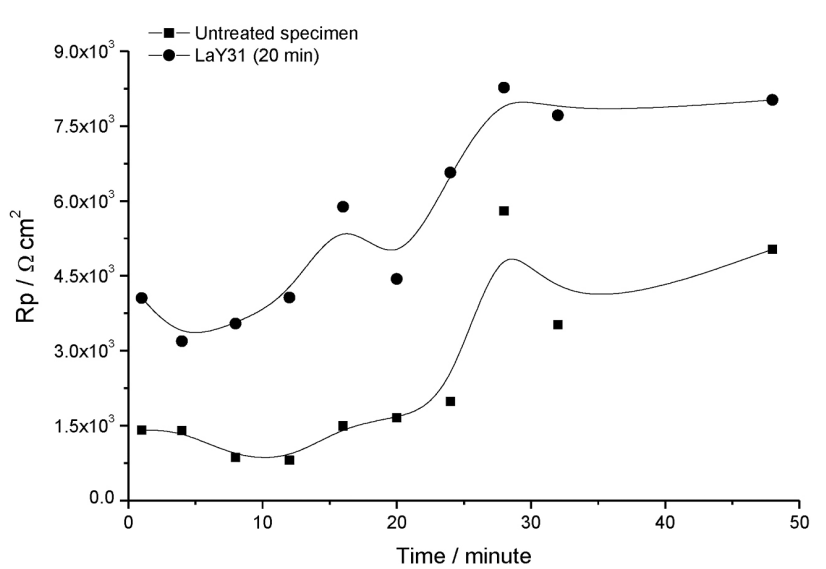

Figure 7: Variation in the polarization resistance versus time during immersion in the $5 \mathrm{~g} / \mathrm{L} \mathrm{NaCl}$ solution at room temperature

where $Q\left(F s^{\alpha-1}\right)$ is the admittance and $\alpha(-1 \leq \alpha \leq 1)$ is the dispersion factor expressing the deviation from the ideal behavior.

The EIS parameters obtained by fitting the experimental data are summarized in Table 3. The internalresistance value, $R_{i}$, remains in the same order of magnitude whereas the faradic resistance, $R_{\mathrm{f}}$, is improved by more than 2 and 2.5 times for the specimens treated for $10 \mathrm{~min}$ and $20 \mathrm{~min}$, respectively. The obtained chi-squares $\left(\chi^{2}\right)$ are of the order of $10^{-3}$, indicating a good fitting of the experimental data.

Table 3: EIS parameters for the aluminum-alloy specimens

\begin{tabular}{|l|cc|cc|cc|}
\hline & $\begin{array}{c}\text { Untreated error } \\
(\%)\end{array}$ & \multicolumn{2}{|c|}{$\begin{array}{c}\text { min error } \\
(\%)\end{array}$} & \multicolumn{2}{|c|}{$\begin{array}{c}20 \text { min error } \\
(\%)\end{array}$} \\
\hline$R_{\mathrm{i}}(\Omega)$ & 47.6 & 0.55 & 42.6 & 2.03 & 37.7 & 1.56 \\
\hline$R_{\mathrm{tc1}}(\Omega)$ & - & - & 569 & 39.1 & 531 & 37.9 \\
\hline$Q_{\mathrm{dl}}\left(\mu \mathrm{F} . \mathrm{s}^{-1}\right)$ & - & - & 44.9 & 16.4 & 68.9 & 15.3 \\
\hline$\alpha_{\mathrm{dl}}$ & - & - & 0.64 & 2.68 & 0.68 & 2.47 \\
\hline$R_{\mathrm{f}}(\Omega)$ & 3176 & 2.04 & 6695 & 5.18 & 8119 & 3.67 \\
\hline$Q_{\mathrm{b}}\left(\mu \mathrm{F} . \mathrm{s}^{-1}\right)$ & 7.96 & 3.88 & 8.03 & 5.85 & 10.5 & 4.05 \\
\hline$\alpha_{\mathrm{b}}$ & 0.92 & 0.63 & 0.92 & 2.90 & 0.99 & 2.19 \\
\hline$\chi^{2}\left(\times 10^{3}\right)$ & 3.53 & - & 1.34 & - & 1.88 & - \\
\hline
\end{tabular}

\subsubsection{Immersion test}

In Figure 8, we see the variation in the polarization resistance $\left(R_{\mathrm{p}}\right)$ versus time during the immersion in the $5 \mathrm{~g} / \mathrm{L} \mathrm{NaCl}$ solution, at room temperature. The treated aluminum alloy exhibits a significant enhancement in the corrosion behavior in the presence of chloride ions. Indeed, after $48 \mathrm{~h}$, the polarization-resistance value increases nearly 2 times. These results are in agreement with the explanation given by A. Pardo et al. ${ }^{25}$ after studying the Ce-conversion and electrolysis surface treatments applied to $\mathrm{A} 3 \mathrm{xxx}$ alloys and $\mathrm{A} 3 \mathrm{xxx} / \mathrm{SiCp}$ composites; they argue that chloride ions favor the initial pitting attack producing Ce-oxides/hydroxides deposits which block the cathodic sites, and therefore increase the protection. In addition, the micrograph in Figure 8 indicates that the specimen is weakly affected by the aggresivity

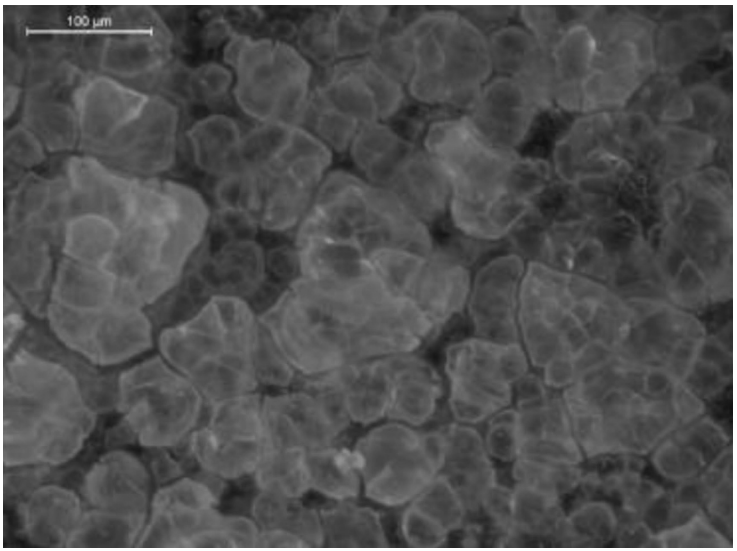

Figure 8: Morphology of the Y/La-conversion coating performed at $2.5 \mathrm{~mA}$ for $20 \mathrm{~min}$, after immersion in the $5 \mathrm{~g} / \mathrm{L} \mathrm{NaCl}$ solution for $48 \mathrm{~h}$

of the chloride-contining media, and no apparent corrosion product is detected with optical microscopy.

The obtained results indicate a good efficiency of the applied yttrium- and lanthanum-conversion coating treatment against the corrosion of the 6061-T6 aluminum alloys.

\section{CONCLUSION}

In the present work, yttrium- and lanthanum-conversion coatings for the 6061-T6 aluminum alloy were applied with cathodic electrodeposition using Y- and La-nitrate aqueous solutions, for the corrosion protection in chloride-containing media. Cyclic-voltammetry (CV) curves indicate that the optimal $\left[\mathrm{La}^{3+}\right] /\left[\mathrm{Y}^{3+}\right]$ ratio, providing the necessary amounts of $\mathrm{OH}^{-}$ions for the electrodeposition is 3/1. A typical compact La/Y-conversion coating deposited over the entire substrate surface was revealed using optical microscopy. The microstructure appears as homogenous agglomerates of particles with no particular orientation and grain sizes in a range of $10-150 \mu \mathrm{m}$. The images of the film surfaces after the immersion in the $5-\mathrm{g} / \mathrm{L} \mathrm{NaCl}$ solution, obtained with micrography, reveal that the 6061 specimen is poorly affected by the aggresivity of the chloride-contining media after $48 \mathrm{~h}$. The linear polarization and EIS tests show an improvement in the corrosion resistance, indicating a good efficiency of the applied yttrium- and lanthanum-conversion coating. The inhibiting efficiency $(\eta)$ increases with the treatment time; it was calculated to be $98 \%$ for the time treatment of $20 \mathrm{~min}$.

\section{REFERENCES}

${ }^{1}$ N. C. T. Martins, T. Moura Silva, M. F. Montemor, J. C. S. Fernandes, M. G. S. Ferreira, Electrodeposition and characterization of polypyrrole films on aluminium alloy 6061-T6, Electrochim. Acta, 53 (2008), 4754-4763, doi:10.1016/j.electacta.2008.01.059

${ }^{2}$ H.-Y. Ding, Z.-D. Dai, S.-C. Skuiry, D. Hui, Corrosion wear behaviors of micro-arc oxidation coating of $\mathrm{Al}_{2} \mathrm{O}_{3}$ on $2024 \mathrm{Al}$ in different aqueous environments at fretting contact, Singapour, 2008, 43 (2010) $5-6,868-875$ 
${ }^{3}$ B. Valdez, S. Kiyota, M. Stoytcheva, R. Zlatev, J. M. Bastidas, Cerium-based conversion coatings to improve the corrosion resistance of aluminium alloy 6061-T6, Corros. Sci., 87 (2014), 141-149, doi:10.1016/j.corsci.2014.06.023

${ }^{4}$ F. M. Queiroz, M. Magnani, I. Costa, H. G. de Melo, Investigation of the corrosion behaviour of AA 2024-T3 in low concentrated chloride media, Corrosion Science, 50 (2008), 2646-2657, doi:10.1016/ j.corsci.2008.06.041

${ }^{5}$ P. Leblanc, G. S. Frankel, A study of corrosion and pitting initiation of AA2024-T3 using atomic force microscopy, J. Electrochem. Soc., 149 (2002) 6, B239-B247, doi:10.1149/1.1471546

${ }^{6}$ P. Schmutz, G. S. Frankel, Characterization of AA2024-T3 by scanning kelvin probe force microscopy, J. Electrochem. Soc., 145 (1998) 7, 2285-2295, doi:10.1149/1.1838633

${ }^{7}$ Z. Szklarska-Smialowska, Pitting corrosion of aluminum, Corros Sci., 41 (1999) 9, 1743-1767, doi:10.1016/S0010-938X(99)00012-8

${ }^{8}$ F. Gharavi, K.-A. Matori, R. Yunus, N.-K. Othman, F. Fadaeifard, Corrosion behavior of Al6061 alloy weldment produced by friction stir welding process, J. Mater. Res. Technol., 4 (2015) 3, 314-322, doi:10.1016/j.jmrt.2015.01.007

${ }^{9}$ S. P. Ringer, K. Hono, Microstructural evolution and age hardening in aluminum alloys: atom probe field-ion microscopy and transmission electron microscopy studies, Mater. Charact., 44 (2000) 1-2, 101-131, doi:10.1016/S1044-5803(99)00051-0

${ }^{10}$ V. Guillaumin, G. Mankowski, Localized corrosion of 2024 T351 aluminum alloy in chloride media, Corros. Sci., 41 (1998) 3, $421-438$

${ }^{11}$ J. Guertin, J. A. Jacobs, C. P. Avakian, Chromium(VI) Handbook, CRC Press, Florida, 2005

${ }^{12}$ J. Gulcovski, J. Bajat, V. Miscovic-Stankovic, B. Jokic, V. Panic, S. Milonjic, Cerium oxide as conversion coating for the corrosion protection of aluminum, J. Electrochem. Sci. Eng., 3 (2013) 4, 151-156, doi: $10.5599 / 105$

${ }^{13}$ H. D. Johansen, C. M. A. Brett, A. J. Motheo, Corrosion protection of aluminum alloy by cerium conversion and conducting polymer duplex coatings, Corros. Sci., 62 (2012), 342-350, doi:10.1016/ j.corsci.2012.06.020

${ }^{14}$ G. R. Salazar-Branda, S. R. Moraes, A. J. Motheo, S. A. S. Machado, Anticorrosive cerium-based coatings prepared by the sol-gel method, J. Sol-Gel Sci. Technol., 52 (2009) 3, 425-423, doi:10.1007/ s10971-009-2031-1
${ }^{15}$ Y. Xingwen, C. Chunan, Y. Zhiming, Z. Derui, Y. Zhongda, Study of double layer rare earth metal conversion coatings on aluminum alloy LY12, Corros. Sci., 43 (2001) 7, 1283-1294, doi:10.1016/S0010938X(00)00141-4

${ }^{16}$ Y.-R. Luo, R. H. Byrne, The Influence of Ionic Strength on Yttrium and Rare Earth Element Complexation by Fluoride Ions in $\mathrm{NaClO}_{4}$, $\mathrm{NaNO}_{3}$ and $\mathrm{NaCl}$ Solutions at $25{ }^{\circ} \mathrm{C}$, J. of Solution Chem., 36 (2007), 673-689, doi:10.1007/s10953-007-9141-6

${ }^{17}$ Handbook of chemistry and physics ( $84^{\text {th }}$ edn.), D. R. Lide (ed.), CRC Press, Florida, 2003

${ }^{18}$ S. B. Brachetti-Sibaja, M. A. Domínguez-Crespo, A. M. TorresHuerta et al., Rare Earth Conversion Coatings Grown on AA6061 Aluminum Alloys: Corrosion Studies, J. Mex. Chem. Soc., 58 (2014) 4, 393-410

${ }^{19}$ B. Bouchaud, J. Balmain, G. Bonnet, F. Pedraz, Correlations between electrochemical mechanisms and growth of ceria-based coatings onto nickel substrates, Electrochim. Acta, 88 (2013) 798-806, doi:10.1016/j.electacta.2012.10.112

${ }^{20}$ S. Kiyota, B. Valdez, M. Stoytcheva, R. Zlatev, J. M. Bastidas, Anticorrosion behavior of conversion coatings obtained from unbuffered cerium salt solutions on AA6061-T6, J. Rare Earth, 29 (2011) 10, 961-968, doi:10.1016/S1002-0721(10)60579-0

${ }^{21}$ J. R. Scully, Electrochemical tests, corrosion tests and standards: application and interpretation ( $2^{\text {nd }}$ ed.), R. Badoian (ed.), ASTM International, 1995, 107-130

${ }^{22}$ Lj. S. Zivkovic, L. P. Popic, B. V. Jegdic et al., Corrosion study of ceria coatings on AA6060 aluminum alloy obtained by cathodic electrodeposition: Effect of deposition potential, Surf. Coat. Technol., 240 (2014), 327-335, doi:10.1016/j.surfcoat.2013.12.048

${ }^{23}$ J. Sun, G. Wang, Preparation and corrosion resistance of cerium conversion coatings on AZ91D magnesium alloy by a cathodic electrochemical treatment, Surf. Coat. Technol., 254 (2014), 42-48, doi:10.1016/j.surfcoat.2014.05.054

${ }^{24}$ A. Abdi, O. Aaboubi, M. Trari, Investigation on structural, morphological, and electrochemical properties of mesoporous cobalt oxide-infiltrated NaY zeolite, J. Solid State Electr., 21 (2016) 2, 383-390, doi:10.1007/s10008-016-3378-1

${ }^{25}$ A. Pardo, M. C. Merino, R. Arrabal, F. Viejo, J. A. Muñoz, Ce conversion and electrolysis surface treatments applied to A3xx.x alloys and A3xx.x/SiCp composites, Appl. Surf. Sci., 253 (2007) 6, 3334-3344, doi:10.1016/j.apsusc.2006.07.028 